\title{
EVALUATION OF THE ECONOMIC RETURN OF PREVENTIVE HEALTH CARE (FRISKKO) AT HERD LEVEL IN DAIRY HERDS IN SWEDEN
}

\author{
Lena Hult \\ Swedish Dairy Association \\ Charlotte Hallén Sandgren \\ Eskilstuna, ${ }^{2}$ Kalmar Tjust Husdjur, Kalmar \\ Swedish Dairy Association, SE-631 84 Eskilstuna, Sweden, Tel: +46 161635 17, \\ E-mail: lena.hult@svenskmjolk.se
}

When a new preventive health care service (FRISKKO) for dairy herds was introduced in the county of Kalmar, Sweden, an attempt was made to evaluate the economic benefit of improved animal health in the participating herds.

The basic FRISKKO service includes one visit annually by the veterinary practitioner and a veterinary officer from the local livestock society. All herd issues, from calves to cows, are discussed with the owner and farm employees. After the visit, the farmer receives a written document produced by the veterinarians and most often also an advisory officer specialising in feeding, covering advice and guidance. The veterinary practitioner makes a follow-up visit to the farm after approximately 6 months.

During the visit, a review is also made of the key health parameters produced specifically for the herd in question. These parameters, which indicate the herd health status in comparison with other herds, are based on data from the dairy, the AI recording, milk-recording and animal disease recording systems.

The evaluation was made by comparing these key parameters in a trial group of 40 herds with a control group of 199 herds, before the FRISKKO service was initiated, and after 1 and 3 years. The control group was selected to conform with the trial group in terms of geographical area, size, production and health key parameters when the evaluation started. The result was recorded as differences from the initial position. Factors allocated economic weights were: $\mathrm{kg}$ produced milk; increased age at first calving; prolonged average calving interval; increased number of inseminations per series; cases of mastitis treated by a veterinarian; other diseases requiring veterinary treatment; number of culled cows, and produced but not delivered milk.

Production growth was the same in both groups after one year, but costs caused by health disturbances had dropped in the trial group by 300 SEK per cow and year. After 3 years, the production had further increased equally much in both groups, but the profit in the trial group had gone up to 600 SEK per cow and year due to improved animal health. The cost for the service was 100 SEK per cow and year.

The conclusion is that preventive advisory services according to the FRISKKO concept result in improved animal health and production economy in the herd.

\section{References}

Hallén-Sandgren C et al.2000. FRISKKO-Friskvård med helhetsperspektiv. Svensk Veterinärtidning 2000 Volym52 nr1 